\title{
CHARACTERIZATION OF THERMALLY STABLE DYE-DOPED POLYIMIDE BASED ELECTROOPTIC MATERIALS
}

MICHAEL B. MEINHARDT*, PAUL A. CAHILL*, CARL H. SEAGER*, ALLYSON J. BEUHLER** AND DAVID A. WARGOWSKI**

*Sandia National Laboratories, Albuquerque, NM 87185

**Amoco Chemical Company, Naperville, IL 60566

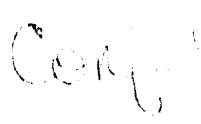

\section{ABSTRACT}

Preparation and characterization of novel dye-doped polyimide films for electrooptics is described. Thermal stabilities of donor-acceptor 2,5-diaryl oxazoles were evaluated by differential scanning calorimetry. Absorptive losses in thin films of Ultradel 9000D ${ }^{\circledR}$ doped with donor-acceptor oxazoles were measured by photothermal deflection spectroscopy. Absorptive losses at high doping levels may be explainable by dye-dye aggregation or dye degradation during the curing process. Lower doping levels, however, show losses of $\leq 3.0$ $\mathrm{dB} / \mathrm{cm}$ at $830 \mathrm{~nm}$ and $\leq 2.4 \mathrm{~dB} / \mathrm{cm}$ at $1320 \mathrm{~nm}$.

\section{INTRODUCTION}

Polymeric electrooptic materials have the potential to replace electronic switches in applications which require minimization of heat dissipation while maintaining high switching speeds. Polyimide matrices incorporating electrooptic dyes are promising materials for such applications due to their low cost and compatibility with existing processing environments. Requirements for practical systems include large electrooptic coefficients, thermal stability, high $\mathrm{T}_{\mathrm{g}}$, refractive index differences (waveguide formation), conductivity (poling and data impression) and low optical loss (transmission). ${ }^{1}$ (Figure 1).

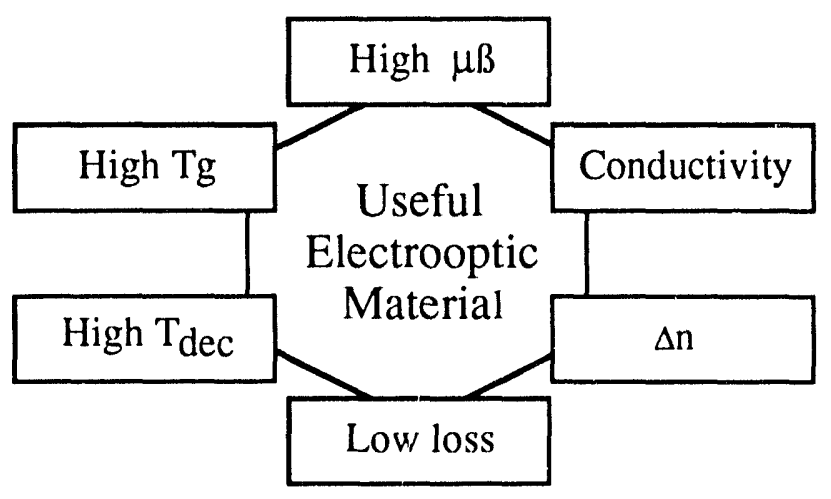

Figure 1. Property-performance criteria for electrooptic materials.

Amoco Ultradel $9000 \mathrm{D}^{\circledR}$ aromatic polyimides (Fig. 2, below) are a family of $\boldsymbol{\gamma}$-butyrolactone (GBL) soluble, fully imidized, fluorinated polyimides developed for integrated optical applications. Thermal or photochemical cross-linking imparts a $\mathrm{Tg}$ approaching $400{ }^{\circ} \mathrm{C}$ and 
provides stability for poled polymer systems. Excellent optical transparencies have also been demonstrated in these materials. ${ }^{2}$

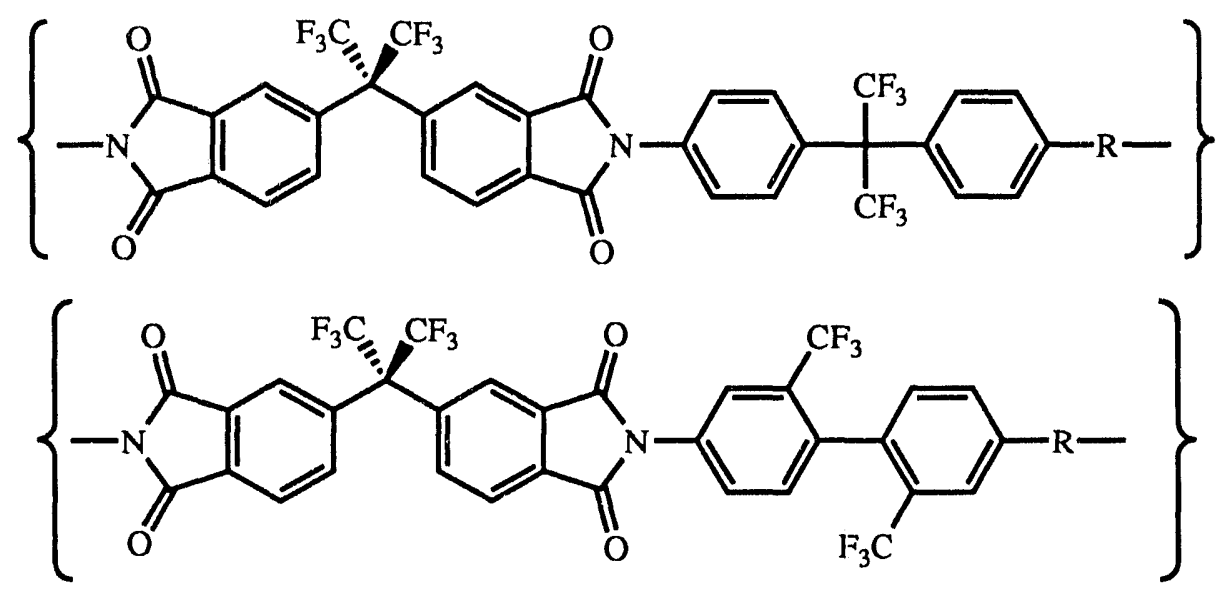

Figure 2: Amoco Ultradel 9000D ${ }^{\circledR}$ Electrooptic Polyimides.

Previously we reported results of characterization of Ultradel polyimides for electrooptic applications, as well as properties of these polymers heavily doped with donor-acceptor triaryl azole dyes (I). ${ }^{3}$ (Figure 3 ). In this study we have extended our investigations to examine novel diaryl oxazoles (II) and their properties in polyimide electrooptic films. Computational studies suggested that linear and nonlinear optical properties of diaryl oxazoles should be similar to their triaryl counterparts with the advantage of a higher nonlinearity to weight ratio. Thus, we undertook the synthesis and characterization of novel dyes II a-c.
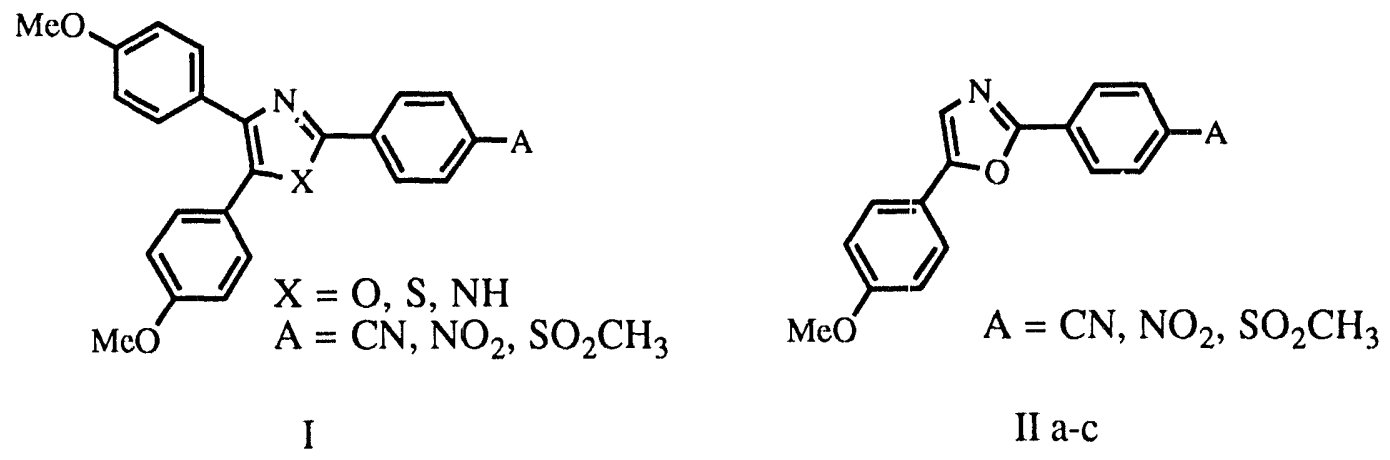

II a-c

Figure 3: Donor-acceptor triaryl- and diaryl-azoles.

\section{RESULTS AND DISCUSSION}

Triaryl oxazoles were prepared in multi-gram lots by condensation of an appropriate benzamide with anisoin in the presence of an acid catalyst. ${ }^{4}$ (Figure 4.) A more elaborate route was developed to achieve the regioselectivity required of the diaryl oxazoles. For example, 4cyanobenzoyl chloride was condensed with 2-amino-(4-methoxyphenyl)ethanone via a modified 
Schötten-Baumann procedure 5 to give a 2-aza-1,4-butadione. Ring closure and dehydration were accomplished by refluxing the azadione in phosphorous oxychloride. 6<smiles>COc1ccc(C(=O)C(O)c2ccc(OC)cc2)cc1</smiles><smiles>COc1ccc(-c2nc(-c3ccc(OC)cc3)c(-c3ccc(I)cc3)o2)cc1</smiles>

I a-c<smiles>COc1ccc(C(=O)CNC(=O)c2ccc([Tl])cc2)cc1</smiles><smiles>COc1ccc(-c2cnc(-c3ccc([Tl])cc3)o2)cc1</smiles>

Figure 4: Synthesis of Donor-Acceptor Triaryl- and Diaryl-Oxazoles.

Compatibility with Ultradel $9000 \mathrm{D}^{\circledR}$ processing conditions demands dye thermal stability at $300{ }^{\circ} \mathrm{C}$ for one hour during the curing cycle. Thus, DSC studies were undertaken to evaluate the thermal stability of these dyes. Semi-preparative HPLC methods provided dye samples of high purity ( $>99 \%$ ). Novel donor-acceptor oxazole dyes were assayed for thermal stability using sealed tube methods in order to eliminate concerns of dye sublimation during the

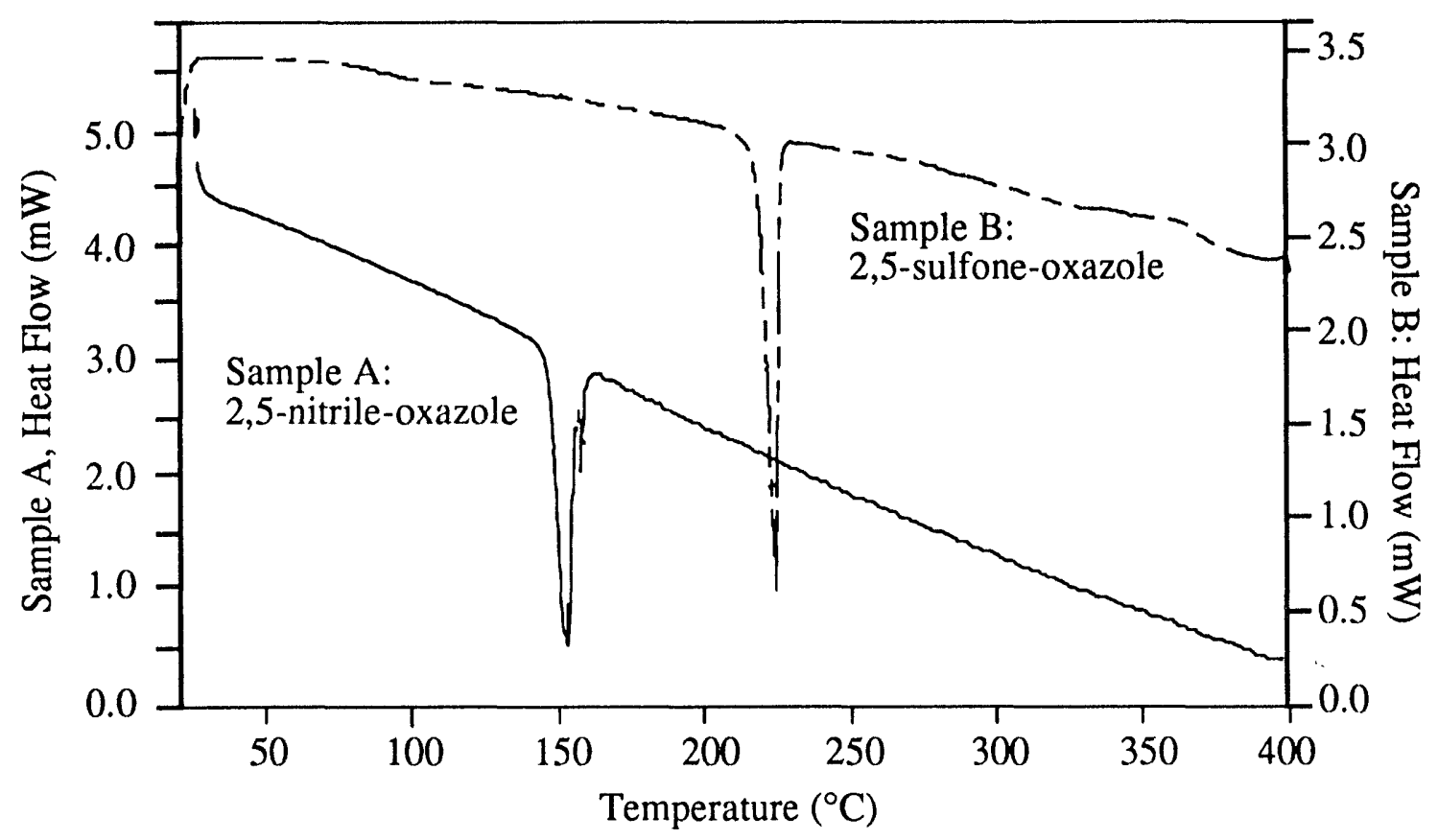

Figure 5: Sealed Tube DSC Spectra of Acceptor-Substituted Diaryl-Oxazoles (II-a,b). 
DSC experiment. ${ }^{7}$ Samples of $\sim 1 \mathrm{mg}$ were sealed into $1.5 \times 7.0 \mathrm{~mm}$ glass capillary tubes and inserted into aluminum holders designed to fit into a Perkin-Elmer DSC 7 and heated at 10 ${ }^{\circ} \mathrm{C} / \mathrm{min}$ from $25-400{ }^{\circ} \mathrm{C}$. The results from two experiments are shown in Figure 5 .

From Table 1 , below, no signs of thermal decomposition were observed below $400{ }^{\circ} \mathrm{C}$ for nitrile and sulfonyl substituted di- and triaryl oxazoles. Nitro compounds, in contrast, exhibited marked thermal decomposition exotherms with decomposition onset temperatures of $360-365{ }^{\circ} \mathrm{C}$, conditions only marginally compatible with polyimide curing conditions. Nitro aromatics are also oxidants which may lead to long-term stability problems. As a result of these experiments nitrile and sulfonyl substituted diaryl oxazoles were selected for polymer doping studies.

Table 1: Summary of DSC Data for Donor-Acceptor Oxazoles.

\begin{tabular}{|c|c|c|c|}
\hline Compound & $\mathrm{T}_{\text {m.p. }}\left({ }^{\circ} \mathrm{C}\right)$ & $\mathrm{T}_{\text {dec., }}$ max. $\left({ }^{\circ} \mathrm{C}\right)$ & $\mathrm{T}_{\text {Onset, dec. }}\left({ }^{\circ} \mathrm{C}\right)$ \\
\hline 2,5 -nitrile & 155 & $>400$ & $>400$ \\
\hline 2,5 -nitro & 167 & 385 & 361 \\
\hline 2,5 -sulfone & 219 & $>400$ & $>400$ \\
\hline $2,4,5$-nitrile & 183 & $>400$ & $>400$ \\
\hline $2,4,5$-nitro & 207 & 396 & 364 \\
\hline $2,4,5$-sulfone & 210 & $>400$ & $>400$ \\
\hline
\end{tabular}

Photothermal deflection spectroscopy (PDS) provides a method for determining absorptive losses in thin films independent of scattering loss. PDS spectra of triaryl oxazoles Ia,b were previously reported. ${ }^{2}$ We now present similar results for 2,5-nitrile-oxazole (II-a) at varying concentrations of 5 to $20 \%$-wt. DCM-doped polyimide was also examined for comparison. $\gamma$-Butyrolactone (GBL) solutions of polymer or polymer-dye combinations were spin coated onto infrasil quartz wafers and cured in a nitrogen-purged oven for $10 \mathrm{~min}$ at 100 ${ }^{\circ} \mathrm{C}, 30 \mathrm{~min}$ at $175^{\circ} \mathrm{C}$ and $60 \mathrm{~min}$ at $300^{\circ} \mathrm{C}$. Sample thicknesses were measured on a Sloan Dektak profilometer and varied from 8 to $18 \mu \mathrm{m} \pm 1 \mu \mathrm{m}$. The results of PDS measurements for 2,5-nitrile-oxazole and DCM doped Ultradel $9000 \mathrm{D}^{\circledR}$ films are given in Figure 6.

Loss values for the undoped Ultradel $9000 \mathrm{D}^{\circledR}$ are well within performance criteria of $<$ $1.5 \mathrm{~dB} / \mathrm{cm}$ for electrooptic devices. ${ }^{1}$ Minimum loss in doped and undoped samples occurs near $1060 \mathrm{~nm}$. Optical losses for pure Ultradel $9000 \mathrm{D}^{\circledR}$ cured at $300^{\circ} \mathrm{C}$ are at or below $1 \mathrm{~dB} / \mathrm{cm}$ in the range 850-1350 nm. For dye-doped samples, losses are below $3 \mathrm{~dB} / \mathrm{cm}$ in the same region. At $1060 \mathrm{~nm}$, loss for $20 \%$-wt 2,5-nitrile-oxazole samples was $0.5-0.7 \mathrm{~dB} / \mathrm{cm}$ greater than for the 5 or $10 \%$-wt samples. These losses were the subject of further investigations (vide infra). DCM doped $U 9000 D^{\circledR}$ has lower losses than the 2,5-nitrile-oxazole samples $(1.4 \mathrm{~dB} / \mathrm{cm}$ at $1060 \mathrm{~nm})$ however, this sample was cured at a lower temperature $\left(250^{\circ} \mathrm{C}\right)$ due to excessive thermal decomposition at $300^{\circ} \mathrm{C}$.

\section{DISCLAIMER}

This report was prepared as an account of work sponsored by an agency of the United States Government. Neither the United States Government nor any agency thereof, nor any of their employees, makes any warranty, express or implied, or assumes any legal liability or responsibility for the accuracy, completeness, or usefulness of any information, apparatus, product, or process disclosed, or represents that its use would not infringe privately owned rights. Reference herein to any specific commercial product, process, or service by trade name, trademark, manufacturer, or otherwise does not necessarily constitute or imply its endorsement, recommendation, or favoring by the United States Government or any agency thereof. The views and opinions of authors expressed herein do not necessarily state or reflect those of the United States Government or any agency thereof. 


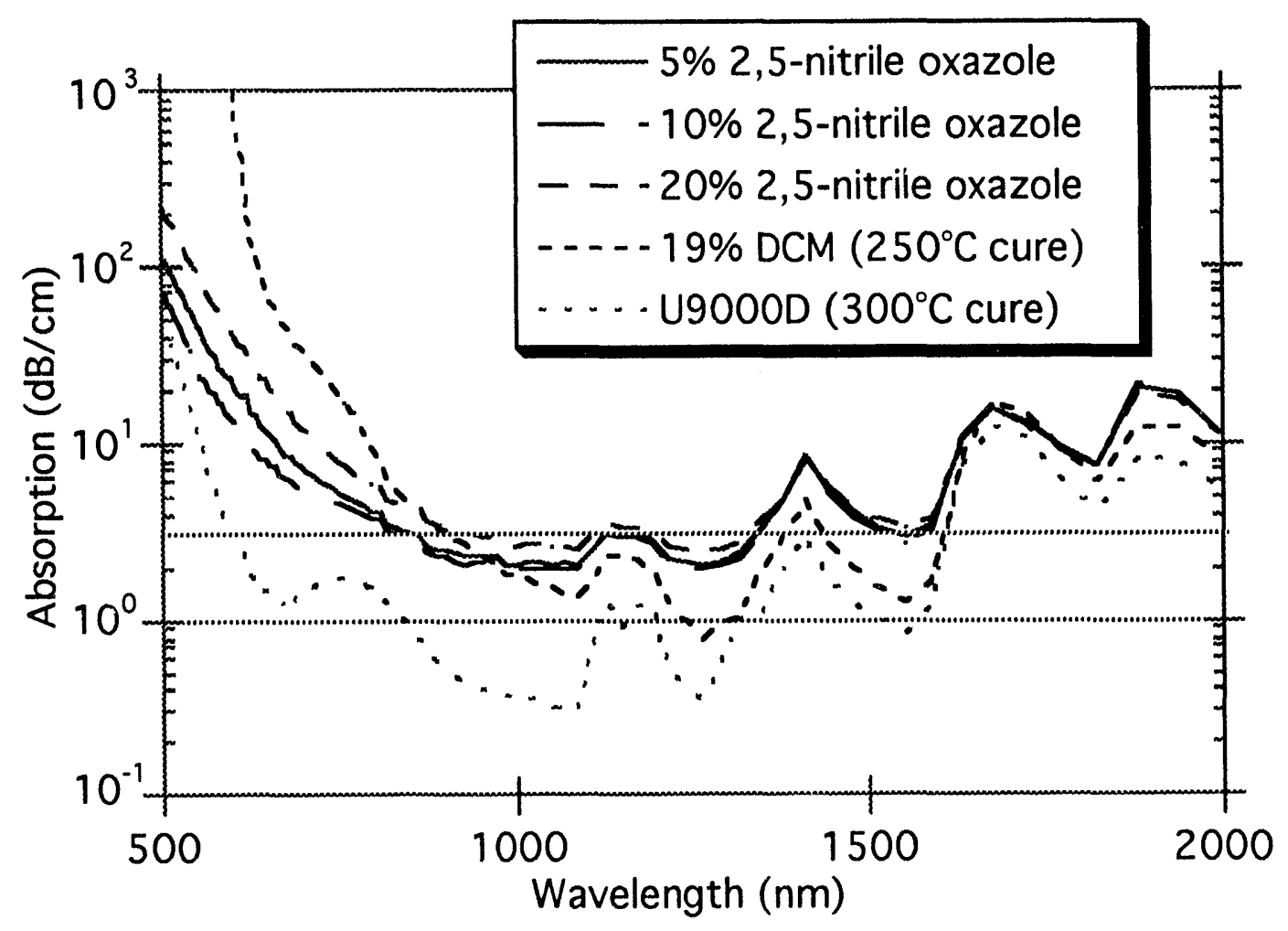

Figure 6: PDS Spectra of 2,5-Nitrile-Oxazole (II-a) Doped Ultradel 9000D ${ }^{\circledR}$.

Table 2: Selected Loss Data for 2,5-Nitrile-Oxazole (II-a) Doped U9000D ${ }^{\circledR}, 300^{\circ} \mathrm{C}$ Cure.

\begin{tabular}{|c|c|c|c|}
\hline Sample & $\mathrm{dB} / \mathrm{cm}_{826 \mathrm{~nm}}$ & $\mathrm{~dB} / \mathrm{cm}_{1069 \mathrm{~nm}}$ & $\mathrm{~dB} / \mathrm{cm}_{132} \mathrm{~nm}$ \\
\hline $5 \%-\mathrm{wt}$ & 3.3 & 2.1 & 2.4 \\
\hline $10 \%-\mathrm{wt}$ & 3.0 & 2.0 & 2.2 \\
\hline $20 \%-\mathrm{wt}$ & 4.5 & 2.6 & 2.7 \\
\hline $\mathrm{DCM}^{(19 \%-\mathrm{wt})}$ & 5.4 & 1.4 & 1.0 \\
\hline $\mathrm{U} 900 \mathrm{D}^{\circledR}$ & 1.2 & 0.32 & 1.0 \\
\hline
\end{tabular}

Notes: DCM sample was cured at $250^{\circ} \mathrm{C}$. Loss for $U 9000 \mathrm{D}^{\circledR}$ at $830 \mathrm{~nm}$ was $0.7 \mathrm{~dB} / \mathrm{cm}$, as determined by waveguide loss spectroscopy. ${ }^{2}$

The origins of optical loss in dye-doped thin films of polyimides are not well understood. While the optical loss associated with the undoped Ultradel $9000 \mathrm{D}^{\circledR}$ is small $(0.3 \mathrm{~dB} / \mathrm{cm}$ at $1060 \mathrm{~nm}$ ) as determined by PDS and waveguide loss spectroscopy ${ }^{2}$, losses for oxazole-doped polyimides are greater $(\sim 1.6-1.8 \mathrm{~dB} / \mathrm{cm})$. Losses are similar at 5 and $10 \%$-wt doping levels, with a jump of $\sim 0.6 \mathrm{~dB} / \mathrm{cm}$ at $1060 \mathrm{~nm}$ for the $20 \%$-wt sample. The origin of this additional loss was the subject of further investigations.

We sought to examine the question of the added loss in 20\%-wt 2,5-nitrile-oxazole by UV-Vis absorption studies. There is precedent for short-wavelength polymeric charge transfer absorptions in polyimides. ${ }^{8}$ We sought to examine the potential for dye-matrix interactions as the origin of the additional absorptions. Variation of solvent polarity was hypothesized to enhance the opportunity for dye-matrix charge transfer. For example broad, weak charge 
transfer from anisole to the cyanophenyl ring might be expected to give rise to long-wavelength absorptions.

UV-Vis absorption spectra for triaryl nitrile-oxazole were determined in solvents of varying polarity. Dilute solutions $\left(\sim 10^{-5} \mathrm{M}\right)$ of HPLC purified dyes were employed to eliminate concerns of spurious absorptions arising from dye-dye or dye-impurity interactions. Cell path lengths of $10.0 \mathrm{~cm}$ were used to maximize small absorption signals. Within experimental limits, no discernible charge-transfer absorptions were observed in any dye-solvent system in the region $600-900 \mathrm{~nm}$. Minor solvatochromic effects were observed for absorption maxima. ${ }^{9}$

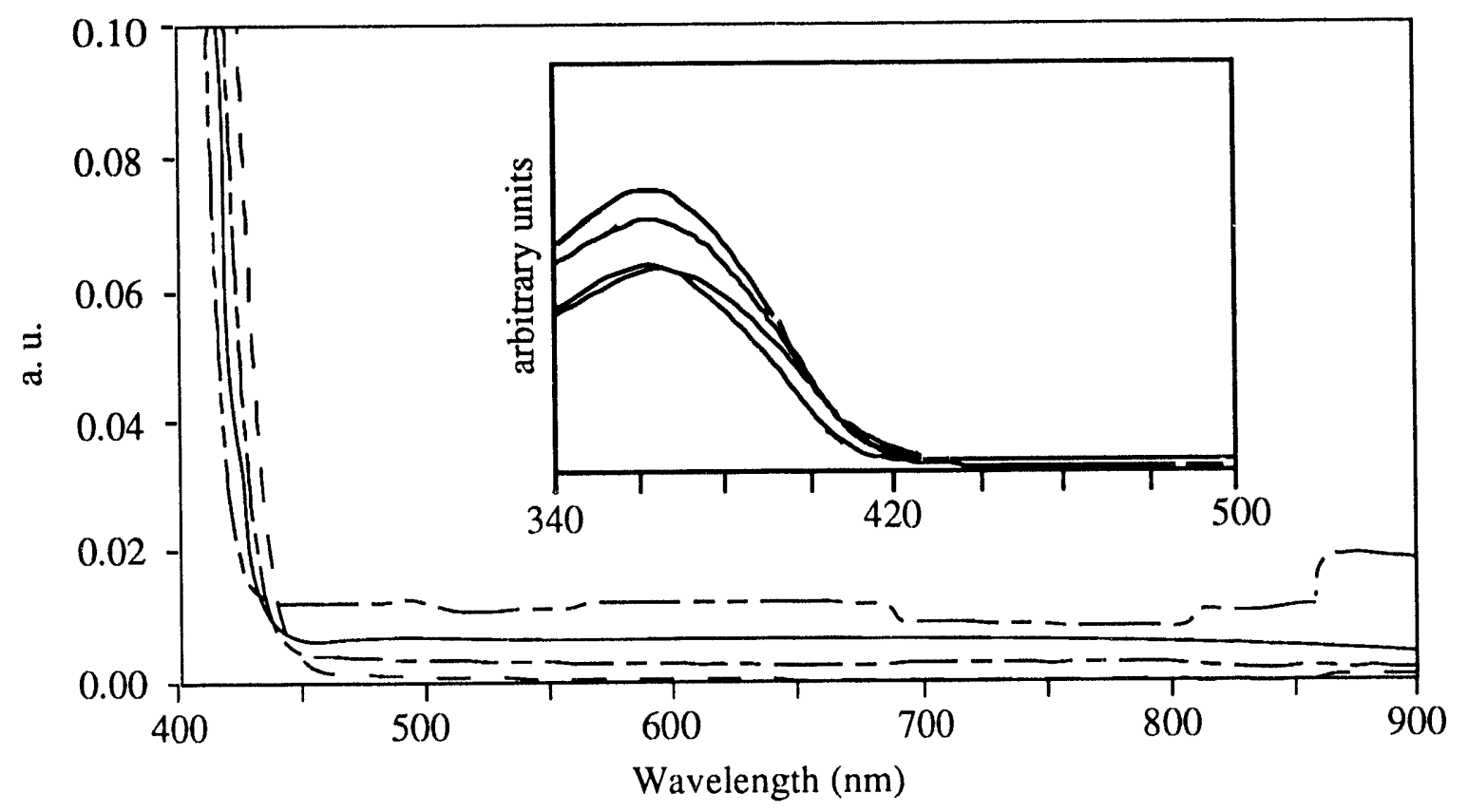

Figure 6: UV-Vis absorption spectra for nitrile-oxazole (I) in various solvents. Solvent (in descending order at $600 \mathrm{~nm}$ ) benzene, ethyl benzoate, anisole and benzonitrile. Inset: solvent (in descending order at $360 \mathrm{~nm}$ ) anisole, ethyl benzoate, benzonitrile and benzene.

DSC studies have demonstrated the excellent thermal stabilities of novel diaryl nitrile and sulfone dyes (II-a,c). In addition, dye-doped Ultradel $9000 \mathrm{D}^{\circledR}$ samples doped at 5 and $10 \%$ wt exhibit acceptable absorbance losses of $\leq 3 \mathrm{~dB} / \mathrm{cm}$ at 820 and $1320 \mathrm{~nm}$. Higher doping levels give rise to absorbance losses which cannot be explained solely on the basis of Beer's Law. It is clear that absorptive losses do not arise from the polymer itself. Our study of dye-solvent (dyematrix) systems suggests that observed losses are not due to charge transfer interactions between dye and matrix (dye-solvent or dye-polymer).

Possible mechanisms of absorptive loss at high doping levels include dye aggregation and dye degradation during the curing process. PDS samples were free of apparent crystallinity as determined by optical microscopy. DSC samples examined after thermal cycling frequently revealed glassification upon cooling. These observations suggest the difficulty in ascertaining dye-polymer inhomogeneity.

\section{CONCLUSIONS}


DSC studies have demonstrated the excellent thermal stabilities of diaryl nitrile and sulfone oxazoles (II-a,c). In addition, dye-doped Ultradel $9000 \mathrm{D}^{\circledR}$ samples doped with dyes at 5 and 10\%-wt 2,5-nitrile-oxazole (II-a) exhibit acceptable absorbance losses of $<3 \mathrm{~dB} / \mathrm{cm}$ at 1060 $\mathrm{nm}$. Higher doping levels of 2,5-nitrile-oxazole give rise to unexpected absorbance losses. On the basis of this study, it seems apparent that these losses do not arise from either dye-matrix interactions or from the polymer itself. The distinct possibility remains that at high concentrations dye aggregation in cured polyimide films or dye degradation during the cure process may be the ultimate origin of these absorptive losses. Should this be the case, future systems may require enforced chromophore separation by copolymerization of the dye in order to attain losses of $<2 \mathrm{~dB} / \mathrm{cm}$.

\section{EXPERIMENTAL}

2-(4-cyanophenyl)-4,5-bis-(4-methoxyphenyl)oxazole. A solution of $6.51 \mathrm{~g}(32.5 \mathrm{mmol})$ of anisoin and $9.30 \mathrm{~g}(34.1 \mathrm{mmol})$ of 4-bromobenzamide in $75 \mathrm{~mL}$ of 1,4-dioxane was treated with $0.5 \mathrm{~mL}$ of conc. sulfuric acid and heated at reflux for $18 \mathrm{~h}$. Neutral workup provided a crude product which was purified by flash chromatography and recrystallized from ethyl acetate to give 2-(4-bromophenyl)-4,5-bis-(4-methoxyphenyl)oxazole, $8.78 \mathrm{~g}(62 \%) \mathrm{m} . \mathrm{p} .: 168-170^{\circ} \mathrm{C}$.

Next, a solution of the bromide $(4.01 \mathrm{~g}, 9.20 \mathrm{mmol})$ and copper cyanide $(4.12 \mathrm{~g}, 46.0$ mmol) in $N$-methylpyrrolidinone $(125 \mathrm{~mL})$ was heated at $180^{\circ} \mathrm{C}$ for $18 \mathrm{~h}$. The mixture was poured over ice and the precipitated solids collected and dried. Flash chromatography (25\% ethyl acetate-hexane), followed by recrystallization from ethyl acetate gave the desired product, $2.46 \mathrm{~g}(70 \%)$. m.p.: $184-186^{\circ} \mathrm{C}$.

The spectral data for 2-(4-cyanophenyl)-4,5-bis-(4-methoxyphenyl)oxazole were the following: FTIR (KBr) 3045, 3005, 2960, 2935, 2905, 2840, 2225 (CN), 1610, 1520, 1500, $1300,1255,1180,1110,1025,965,840 \mathrm{~cm}^{-1} ;{ }^{1} \mathrm{H} \mathrm{NMR}\left(\mathrm{CDCl}_{3}, 200 \mathrm{MHz}\right) \delta 8.20(\mathrm{~d}, \mathrm{~J}=8.7$ $\mathrm{Hz}, 2 \mathrm{H}$, arom.), 7.73 (d, J = 8.7 Hz, $2 \mathrm{H}$, arom.), 7.59 (m, $4 \mathrm{H}$, arom.), 6.91 (m, $4 \mathrm{H}$, arom.), $3.83\left(\mathrm{~s}, 6 \mathrm{H}, \mathrm{OCH}_{3}\right)$

MS calcd for $\mathrm{C}_{24} \mathrm{H}_{18} \mathrm{~N}_{2} \mathrm{O}_{3}: 382$. Found: m/e 382 .

UV-Vis: $\lambda_{\max }$ (benzene) $362 \mathrm{~nm},\left(\varepsilon_{\max } 14600 \mathrm{~L} \cdot \mathrm{mol}^{-1}\right)$.

(4-methoxyphenyl)-2-aminoethanone hydrochloride. To a stirred solution of (4methoxyphenyl)-2-bromoethanone $(9.85 \mathrm{~g}, 43.0 \mathrm{mmol}$ ) in $300 \mathrm{~mL}$ of absolute ethanol was added $6.33 \mathrm{~g}(45.2 \mathrm{mmol})$ of hexamethylenetetraamine in one portion. After a brief induction period a white precipitate formed. After stirring at $25^{\circ} \mathrm{C}$ for $\delta \mathrm{h}, 70 \mathrm{~mL}$ of a $2.5: 1$ solution of hydrochloric acid in water was added and the mixture stirred at $25^{\circ} \mathrm{C}$ for an additional $8 \mathrm{~h}$. The flask was stoppered and set in a freezer for several days and the crystalline solid was collected by suction filtration washing several times with cold ethanol to give $6.64 \mathrm{~g}(77 \%)$ of the amine hydrochloride. m.p. $204-206^{\circ} \mathrm{C}$, (dec). 
The spectral data for (4-methoxyphenyl)-2-aminoethanone hydrochloride were the following: FTIR (KBr) 3000 (s), 1990, 1685 (CO), 1605, 1505, 1470, 1455, 1430, 1390, 1325, $1270,1255,1180,1130,1060,1020,970,830,810 \mathrm{~cm}^{-1} ;{ }^{1} \mathrm{H} \mathrm{NMR}\left(\mathrm{CDCl}_{3}, 200 \mathrm{MHz}\right) \delta 7.86$ (d, J = 8.9 Hz, $2 \mathrm{H}$, arom.), 6.89 (d, J = 8.9 Hz, $2 \mathrm{H}$, arom.), $4.05\left(\mathrm{~s}, 2 \mathrm{H}, \mathrm{CH}_{2} \mathrm{NH}_{2}\right), 3.82(\mathrm{~s}, 3 \mathrm{H}$, $\left.\mathrm{OCH}_{3}\right)$.

2-(4-cyanophenyl)-4-(4-methoxyphenyl)-2-aza-1,4-butadione. To $50 \mathrm{~mL}$ of an ice cold solution of $0.83 \mathrm{M}$ sodium hydroxide was added $8.07 \mathrm{~g}(40.0 \mathrm{mmol})$ of (4-methoxyphenyl)-2aminoethanone hydrochloride. After $30 \mathrm{~min}$ at $0{ }^{\circ} \mathrm{C}$, a solution of 4-cyanobenzoyl chloride $(6.51$ $\mathrm{g}, 39.3 \mathrm{mmol}$ ) in $60 \mathrm{~mL}$ of tetrahydrofuran was added dropwise concomitantly with $50 \mathrm{~mL}$ of the sodium hydroxide solution over $1.5 \mathrm{~h}$. After the addition was complete, the mixture was stirred for an additional $12 \mathrm{~h}$. The reaction mixture was chilled and the precip: rated product was collected by filtration, dried and used without further purification, $6.01 \mathrm{~g}(52 \%)$, m.p. $190.0-193.5^{\circ} \mathrm{C}$.

The spectral data for 2-(4-cyanophenyl)-4-(4-methoxyphenyl)-2-aza-1,4-butadione were the following: FTIR (KBr) 3340, 3010, 2950, 2840, 2360, 2230, (CN), 1675, 1595, 1560, 1535 , $1495,1460,1435,1420,1365,1310,1265,1240,1175,1115,1025,1005,995,900,855,868$ $\mathrm{cm}^{-1} ;{ }^{1} \mathrm{H} \mathrm{NMR}\left(\mathrm{CDCl}_{3}, 200 \mathrm{MHz}\right) \delta 8.01(\mathrm{~d}, J=9.00 \mathrm{~Hz}, 2 \mathrm{H}$, anisyl), $7.99(\mathrm{~d}, J=8.63 \mathrm{~Hz}, 2$ $\mathrm{H}$, arom.), 7.78 (d, $J=8.63 \mathrm{~Hz}, 2 \mathrm{H}$, arom.), $7.45(\mathrm{~m}, 1 \mathrm{H}, \mathrm{NH}), 7.00(\mathrm{~d}, J=9.00 \mathrm{~Hz}, 2 \mathrm{H}$, anisyl), $4.90\left(\mathrm{~d}, J=4.14 \mathrm{~Hz}, 2 \mathrm{H}, \mathrm{CH}_{2}\right), 3.91\left(\mathrm{~s}, 3 \mathrm{H}, \mathrm{CH}_{3}\right)$.

2-(4-cyanophenyl)-5-(4-methoxyphenyl)oxazole. A solution of $6.01 \mathrm{~g}(20.4 \mathrm{mmol})$ of 2-(4cyanophenyl)-4-(4-methoxyphenyl)-2-aza-1,4-butadione in $50 \mathrm{~mL}$ of $\mathrm{POCl}_{3}$ was heated at reflux for $5 \mathrm{~h}$. Excess $\mathrm{POCl}_{3}$ was removed by vacuum distillation and the residual solids were suspended in water and collected by suction filtration to give $5.18 \mathrm{~g}$ of a crude product, m.p.: $156-158{ }^{\circ} \mathrm{C}$. Recrystallization from acetonitrile provided $3.90 \mathrm{~g}(69 \%)$ of pure product, m.p. $151.5-153.0{ }^{\circ} \mathrm{C}$ as pale yellow needles.

The spectral data for 2-(4-cyanophenyl)-5-(4-methoxyphenyl)oxazole were the following: FTIR (KBr) 2995, 2840, $2225(\mathrm{CN}), 1610,1575,1500,1485,1440,1410,1395$, $1280,1255,1175,1130,1115,1060,1025,955,840,825,810 \mathrm{~cm}^{-1} ;{ }^{1} \mathrm{H} \mathrm{NMR}\left(\mathrm{CDCl}_{3}, 200\right.$ $\mathrm{MHz}) \delta 8.18(\mathrm{~d}, J=8.63 \mathrm{~Hz}, 2 \mathrm{H}$, arom.), $7.76(\mathrm{~d}, J=8.63 \mathrm{~Hz}, 2 \mathrm{H}$, arom.), 7.66 (d, $J=8.92$ $\mathrm{Hz}, 2 \mathrm{H}$, anisyl), 7.39 (m, $1 \mathrm{H}, \mathrm{NH}$ ), 6.99 (d, $J=8.92 \mathrm{~Hz}, 2 \mathrm{H}$, anisyl), 3.87 (s, $3 \mathrm{H}, \mathrm{OCH}_{3}$ ).

MS calcd for $\mathrm{C}_{17} \mathrm{H}_{12} \mathrm{~N}_{2} \mathrm{O}_{2}: 276.30$. Found: $m / e 276$.

UV-Vis: $\lambda_{\max }$ (benzene) $350 \mathrm{~nm},\left(\varepsilon_{\max } 27400 \mathrm{~L}^{\mathrm{mol}}{ }^{-1}\right)$.

\section{ACKNOWLEDGMENTS}

This work was performed, in part, at Sandia National Laboratories and was supported by U.S. Department of Energy under contract DE-AC04-94DP85000. The authors wish to acknowledge Ken Singer and Tony Kowalczyk (Case Western Reserve University) for helpful discussions. The technical assistance of C. Allen (Amoco) is aiso acknowledged. 


\section{REFERENCES}

1. R. Lytel, G. F. Lipscomb, J. T. Kinney and E. S. Binkley, in Polymers for Lightwave and Integrated Optics, edited by L. A. Hornak, (Marcel Dekker, Inc., 1992) p. 433.

2. Amoco Chemicals Ultradel $9000 \mathrm{D}^{\circledR}$, Product Bulletin.

3. (a.) P. A. Cahill, C. H. Seager, M. B. Meinhardt, A. J. Beuhler, D. A. Wargowski, K. D. Singer, T. C. Kowalczyk, T. Z. Kosc, Proc. SPIE, 2025-07, 1993. In press. (b.) For examples of related work with triaryl azoles, see: C. R. Moylan, R. D. Miller, R. J. Twieg, K. M. Betterton, V. Y. Lee, T. J. Matray, C. Nguyen, Chem. Mater. $\underline{5}, 1499$ (1993).

4. K. Matsumoto and P. P. K. Ho, U.S. Patent No. 4322428 (30 March, 1982).

5. A. W. Ingersoll and S. H. Babcock, Org. Syn. Coll. Vol. II, 328-330 (1943).

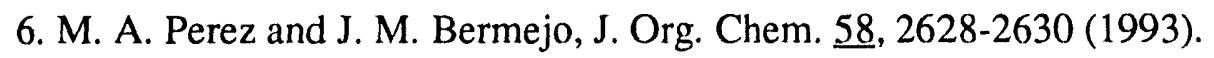

7. L. F. Whiting, M. S. Labean, S. S. Eadie, Thermochemica Acta, 136, 231-245 (1988).

8. J. M. Salley, T. Miwa, C. W. Frank, in Materials Science of High Temperature Polymers for Microelectronics, edited by D. T. Grubb, I. Mita and D. Y. Yoon (Mater. Res. Soc. Proc. 227, Pittsburgh, PA, 1991) pp. 117-124.

9. C. Reichardt, Solvents and Solvent Effects in Organic Chemistry, 2nd ed. (VCH, New York, 1990). 
